\title{
Treatment of Tetramethylpyrazole and 3,5-Diphenylpyrazole with Dialkylaluminum Hydrides - Hydroalumination versus Deprotonation
}

\author{
Werner Uhl and Andreas Vogelpohl \\ Institut für Anorganische und Analytische Chemie der Universität Münster, Corrensstraße 30, \\ 48149 Münster, Germany \\ Reprint requests to Prof. Werner Uhl. E-mail: uhlw@uni-muenster.de \\ Z. Naturforsch. 2010, 65b, 687-694; received March 1, 2010
}

\begin{abstract}
Treatment of tetramethylpyrazole, $\mathrm{N}_{2} \mathrm{C}_{3} \mathrm{Me}_{4}$, with equimolar quantities of di(tert-butyl)aluminum hydride leads to the addition of an $\mathrm{Al}-\mathrm{H}$ bond to one of the $\mathrm{C}=\mathrm{N}$ double bonds. The dimeric product (1) contains a central six-membered $\mathrm{Al}_{2} \mathrm{~N}_{4}$ ring in which two ${ }^{t} \mathrm{Bu}_{2} \mathrm{Al}^{+}$units are bridging two $\mathrm{N}_{2} \mathrm{C}_{3}$ heterocycles. In the zwitterionic, non-centrosymmetric compound one aluminum atom is coordinated by two imino nitrogen atoms, while the second one is bonded to two amide nitrogen atoms. No double hydroalumination occurs upon treatment of tetramethylpyrazole with two equivalents of the hydride. Instead, an adduct (2) of the monomeric hydroalumination product with di(tert-butyl)aluminum hydride was isolated in which the two aluminum atoms are connected by a $3 \mathrm{c}-2 \mathrm{e} \mathrm{Al}-\mathrm{H}-\mathrm{Al}$ bond. A unique trinuclear compound (3) is obtained upon reaction of tetramethylpyrazole with an excess of the sterically less shielded diethylaluminum hydride. It contains two different $\mathrm{N}_{2} \mathrm{C}_{3}$ heterocycles: One still contains a $\mathrm{C}=\mathrm{N}$ double bond similar to that in compounds $\mathbf{1}$ and $\mathbf{2}$, while the second one is completely reduced by double hydroalumination to give a saturated heterocycle. The two rings are bridged by three $\mathrm{AlEt}_{2}$ groups. Deprotonation results upon treatment of 3,5-diphenylpyrazole, $\mathrm{N}_{2} \mathrm{C}_{3} \mathrm{H}_{2}\left(\mathrm{C}_{6} \mathrm{H}_{5}\right)_{2}$, with di(tert-butyl)aluminum hydride.
\end{abstract}

Key words: Organoelement Compounds, Aluminum, Hydrazides, Heterocycles, Hydroalumination

\section{Introduction}

Organoaluminum, -gallium or -indium hydrazides [1] show a fascinating coordination chemistry similar to that of hydroxylamides [2] or peroxides [3] which results from the singular arrangement of two adjacent donor atoms in the ligands. The synthesis of these hydrazides was accomplished via several different and efficient routes such as salt elimination, release of hydrogen or alkanes [1]. The latter method comprises the treatment of the corresponding trialkylaluminum or -gallium compounds with hydrazines having at least one $\mathrm{N}-\mathrm{H}$ function. We preferred this procedure in our recent investigations, because the starting compounds are easily available, and volatile alkanes are formed as the only by-products in usually very selective reactions. Adducts are formed in the first step which could be isolated and characterized in several cases [1, 4-6]. Steric interactions are determining their structures, and in most cases the less shielded nitrogen atoms coordinate to the metal atoms. Only one compound, $\mathrm{Me}_{3} \mathrm{Ga} \leftarrow \mathrm{NH}(\mathrm{Me})-\mathrm{NH}_{2}$ [5], has the more basic alkylated nitrogen atom attached to the metal atom. The release of alkanes from these adducts with the al- most quantitative formation of the corresponding hydrazides takes place spontaneously below room temperature or upon slight warming. The products contain a monoanionic hydrazido ligand and are dimeric with four-, five- or six-membered heterocycles $[1,6-$ 8]. Further reactions gave very interesting oligocyclic or cage-like compounds which have dianionic hydrazinediido groups $[1,5,7,9]$. The latter were also accessible by twofold hydroalumination of tetramethyl2,3-diazabutadiene. However, complete reduction to yield a hydrazinediide occurred only with $\mathrm{AlH}_{3}$ [10], while even an excess of dialkylaluminum hydrides or gallium hydrides gave hydrazone derivatives with an intact $\mathrm{C}=\mathrm{N}$ double bond [11]. In continuation of these investigations we also applied cyclic diaza compounds and treated pyrazole derivatives with dialkylaluminum hydrides.

\section{Results and Discussion}

Reactions of tetramethylpyrazole with $\left(\mathrm{Me}_{3} \mathrm{C}\right)_{2} \mathrm{Al}-\mathrm{H}$

Tetramethylpyrazole was dissolved in toluene and treated with an equimolar quantity of di(tert- 
<smiles>CC1=NN=C(C)C1(C)C</smiles>

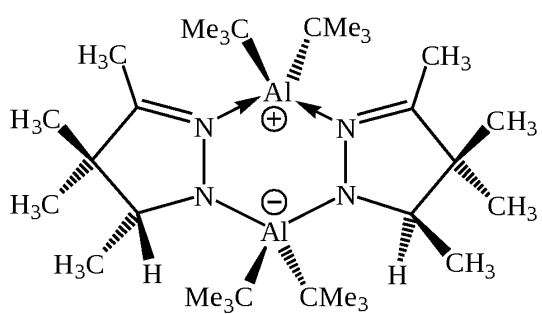

1

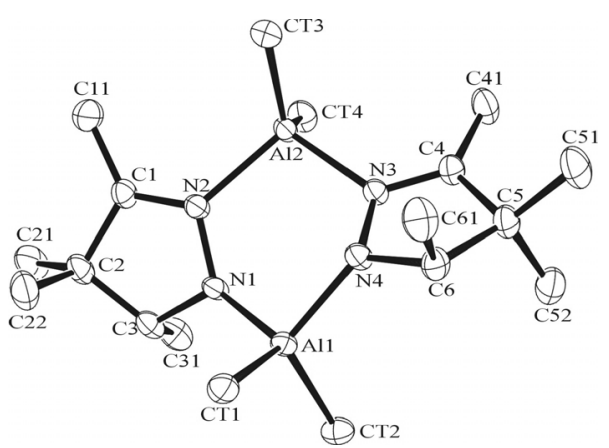

Fig. 1. Molecular structure of $\mathbf{1}$. The ellipsoids are drawn at the $40 \%$ probability level; hydrogen atoms and methyl groups of $\mathrm{CMe}_{3}$ are omitted. Selected bond lengths (pm) and angles (deg): Al1-N1 190.2(2), Al1-N4 190.4(2), A12-N2 198.9(2), Al2-N3 198.6(2), N1-N2 140.1(2), N3N4 139.9(2), N1-C3 149.2(3), N2-C1 130.2(3), N3-C4 130.0(3), N4-C6 149.1(3); N1-A11-N4 100.56(8), N2-Al2N3 101.46(8), Al1-N1-N2 124.4(1), Al1-N4-N3 124.2(1), Al2-N2-N1 118.3(1), Al2-N3-N4 118.9(1).

butyl)aluminum hydride at room temperature. The color of the solution changed from yellow to orange. Concentration of the reaction mixture and cooling to $+3{ }^{\circ} \mathrm{C}$ afforded colorless crystals of the product (1, Eq. 1) in $34 \%$ yield. Crystal structure determination (Fig. 1) revealed a dimeric formula unit in the solid state in which two aluminum atoms bridge two $\mathrm{C}_{3} \mathrm{~N}_{2}$ heterocycles to give a central six-membered $\mathrm{Al}_{2} \mathrm{~N}_{4}$ ring. Only one $\mathrm{C}=\mathrm{N}$ double bond of each pyrazole unit was reduced by the addition of an $\mathrm{Al}-\mathrm{H}$ bond which results in markedly different endocyclic $\mathrm{C}-\mathrm{N}$ bond lengths of $130.1(\mathrm{C}=\mathrm{N}$, average value $)$ and $149.2 \mathrm{pm}$ (average $\mathrm{C}-\mathrm{N}$ single bond). The carbon atoms $\mathrm{C} 1$ and $\mathrm{C} 4$ are $s p^{2}$-hybridized with the adjacent atoms al- most ideally in a common plane, while C2, C3, C5 and C6 have a distorted tetrahedral surrounding. The $\mathrm{N}-\mathrm{N}$ bond length $(140.0 \mathrm{pm})$ is in the lower range of $\mathrm{N}-\mathrm{N}$ single bonds of simple hydrazines $(141-149 \mathrm{pm})$ $[1,12]$. The $\mathrm{Al}_{2} \mathrm{~N}_{4}$ ring deviates considerably from planarity and adopts a twist-conformation [13] (torsion angles: $+55.2,-25.8,-26.7,+54.4,-28.6$, and $-30.7^{\circ}$; clockwise, starting with A11-N1-N2-A12). Caused by this arrangement the normals of the fivemembered rings enclose an angle of $58.7^{\circ}$. Interestingly, the molecular symmetry is not centrosymmetric. One aluminum atom is coordinated by two imino and the second one by two amido nitrogen atoms. This bonding situation results in different Al-N distances (Al2-N 198.8 and Al1-N 190.3 pm, respectively) which are in accordance with previous observations [1, 4-9]. The Al-C distances $(203.0 \mathrm{pm}$ on average) are not influenced by the different coordination of the metal atoms. However, the smaller $\mathrm{C}-\mathrm{Al}-\mathrm{C}$ angle at Al1 (114.1 versus $123.5^{\circ}$ ) may indicate a stronger steric stress at this position. The $\mathrm{N}-\mathrm{Al}-\mathrm{N}$ angles are similar at both aluminum atoms (100.6 versus $\left.101.5^{\circ}\right)$, but the $\mathrm{Al}-\mathrm{N}-\mathrm{N}$ angles are different with the larger ones at the negatively charged amido nitrogen atoms (124.3 versus $118.6^{\circ}$ ).

The NMR data of $\mathbf{1}$ are in accordance with the molecular structure found in the solid state. We observe two resonances of tert-butyl groups and four signals for the chemically different methyl groups attached to the $\mathrm{C}_{3} \mathrm{~N}_{2}$ heterocycle. One of the latter signals is split into a doublet by coupling with the ring hydrogen atom $\left({ }^{3} J_{\mathrm{H}-\mathrm{H}}=6.6 \mathrm{~Hz}\right)$ which also leads to a quartet at $\delta=3.86$. These NMR data verify the existence of dimeric formula units also in solution. Owing to the occurrence of two chiral carbon atoms in the dimeric molecules of $\mathbf{1}$ four different stereoisomers may be formulated. Two of these have a headto-head (symmetry $C_{2}$ according to the structure in the solid state or $C_{S}$ ), the other ones a head-to-tail arrangement $\left(C_{2}\right.$ or $\left.C_{i}\right)$ of the heterocycles. The $C_{s}$ structure should give NMR resonances of four different tertbutyl groups and can clearly be ruled out. The NMR data do not allow to distinguish between the three remaining structures, however, a strong rearrangement compared to the situation in the solid state is necessary to form the head-to-tail isomers, hence, their formation seems to be relatively implausible. An equilibrium between two possible forms in solution was detected for dimeric 2-dimethylaluminumpyridine [14]. In this case warming of the solution gave rearrangement and 
<smiles>CC1=NN=C(C)C1(C)C</smiles>

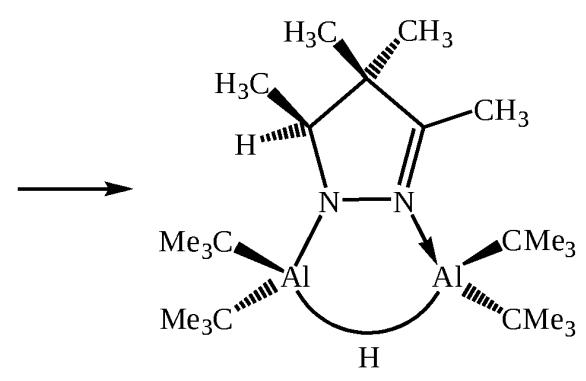

2

complete formation of the centrosymmetric form. We do not have any indication of such an equilibrium for compound $\mathbf{1}$, and heating of $\mathbf{1}$ in boiling toluene did not result in any alteration of the NMR spectra.

The hydroalumination of both $\mathrm{C}=\mathrm{N}$ double bonds in each heterocycle could not be achieved even when an excess of the hydride was reacted with tetramethylpyrazole. Reactions in the ratio $2: 1$ gave an adduct in $72 \%$ yield in which a monomeric fragment of 1 is coordinated by an intact molecule of di(tertbutyl)aluminum hydride via a $3 \mathrm{c}-2 \mathrm{e} \mathrm{Al}-\mathrm{H}-\mathrm{Al}$ bond and an interaction of the metal atom with one of the nitrogen atoms of the $\mathrm{C}_{3} \mathrm{~N}_{2}$ heterocycle (2, Eq. 2). Longer reaction times or warming did not result in any secondary process. The constitution of the yellow compound 2 could unambiguously be assigned from the ${ }^{1} \mathrm{H}$ NMR data. We observed four different resonances of tert-butyl groups which are caused by the different coordination of the aluminum atoms to imino or amido nitrogen atoms and the chirality of the carbon atom bearing a hydrogen atom and a methyl group. Further, we detected four resonances of methyl groups attached to the $\mathrm{C}_{3} \mathrm{~N}_{2}$ ring. Two of the latter resonances are split into doublets. One coupling constant $(6.7 \mathrm{~Hz})$ is characteristic of a ${ }^{3} J_{\mathrm{H}-\mathrm{H}}$ coupling to the hydrogen atom added to the pyrazole ring by hydroalumination. The resonance belongs to the methyl group bonded to the $\mathrm{C}-\mathrm{H}$ fragment of the ring. The occurrence of a second doublet reflects a long-range coupling $\left({ }^{5} J_{\mathrm{H}-\mathrm{H}}=1.0 \mathrm{~Hz}\right)$ between the ring hydrogen atom and the methyl group attached to the $\mathrm{C}=\mathrm{N}$ double bond. Caused by these dif- ferent couplings the ring hydrogen atom gives a quartet of quartets with an expected chemical shift of $\delta=$ 3.43. A broad resonance at $\delta=2.97$ is indicative of a hydrogen atom bridging the two aluminum atoms. The occurrence of a $\mathrm{C}=\mathrm{N}$ double bond is in accordance with a resonance at $\delta=155.9$ in the ${ }^{13} \mathrm{C}$ NMR spectrum $\left(\delta=66.6\right.$ for the $s p^{3}$-hybridized carbon atom bonded to the nitrogen atom). We were not able to determine the structure of $\mathbf{2}$ by X-ray diffraction in sufficient accuracy because all crystals obtained from different solvents ( $n$-pentane, cyclopentane, toluene, 1,2difluorobenzene, diethyl ether etc.) were of very poor quality. The positions of the carbon, nitrogen and aluminum atoms could be found. They have verified the structure of $\mathbf{2}$ given schematically in Eq. 2, but the parameters could not be refined satisfactorily.

\section{Reaction of tetramethylpyrazole with $\mathrm{Et}_{2} \mathrm{Al}-\mathrm{H}$}

Hydroalumination of both $\mathrm{C}=\mathrm{N}$ double bonds of the heterocycle could not be achieved in the reactions of excess di(tert-butyl)aluminum hydride with tetramethylpyrazole. A reason may be the steric shielding by the bulky tert-butyl groups which prevents the second addition reaction. Therefore we reduced the steric demand of the substituents attached to aluminum and treated the pyrazole with two equivalents of diethylaluminum hydride in toluene/n-pentane at r.t. (Eq. 3). The color of the mixture changed from yellow to dark red. Concentration and cooling of the solution to $+3{ }^{\circ} \mathrm{C}$ afforded yellow crystals of compound $\mathbf{3}$ in $67 \%$ yield. A crystal structure determination revealed an interesting and unprecedented molecular structure (Fig. 2) which contains two different five-membered<smiles>CCCCCCCCCC</smiles>

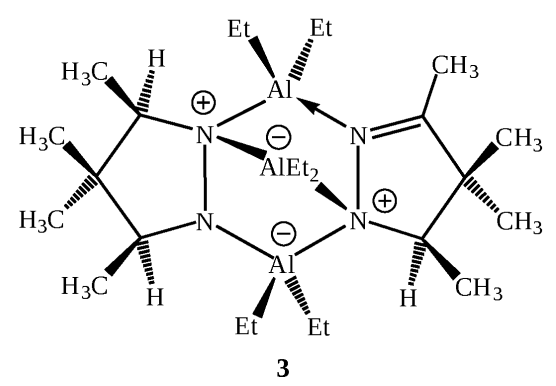




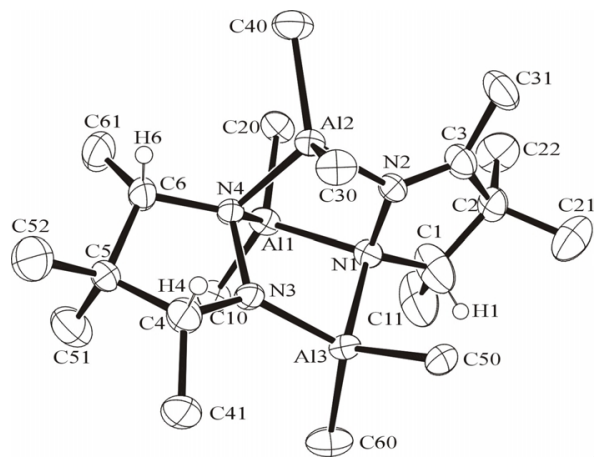

Fig. 2. Molecular structure of $\mathbf{3}$. The ellipsoids are drawn at the $40 \%$ probability level; methyl groups of $\mathrm{CH}_{2} \mathrm{CH}_{3}$ and hydrogen atoms with the exception of $\mathrm{C}-\mathrm{H}$ of the heterocycle are omitted. Selected bond lengths (pm) and angles (deg): Al1-N1 200.3(2), Al1-N4 196.0(2), Al2-N2 200.0(2), Al2-N4 193.5(2), Al3-N1 201.8(2), Al3-N3 185.7(2), N1N2 145.3(3), N3-N4 150.9(3), N1-C1 150.5(4), N2-C3 128.6(3), N3-C4 145.1(3), N4-C6 151.3(3); N1-Al1-N4 86.79(8), N2-Al2-N4 89.10(9), N1-Al3-N3 89.80(9).

$\mathrm{C}_{3} \mathrm{~N}_{2}$ heterocycles. One has still a $\mathrm{C}=\mathrm{N}$ double bond similar to the situation in compounds $\mathbf{1}$ and $\mathbf{2}$ as generated in a single hydroalumination step. The second ring is completely saturated and results from twofold hydroalumination as originally intended. The first heterocycle is planar and has quite different $\mathrm{C}-\mathrm{N}$ bond lengths of $128.6(\mathrm{~N} 2-\mathrm{C} 3)$ and $150.5 \mathrm{pm}(\mathrm{N} 1-\mathrm{C} 1)$ corresponding to the different bond orders, while the second one adopts a twist conformation with both $\mathrm{C}-\mathrm{N}$ bond lengths in the range characteristic of single bonds (N3-C4, $145.1 \mathrm{pm}$; N4-C6, $151.3 \mathrm{pm}$ ). The small difference is caused by the different coordination numbers of three and four at the nitrogen atoms $\mathrm{N} 4$ and N3, respectively. These heterocycles are bridged by three diethylaluminum groups. Two metal atoms ( $\mathrm{Al} 2$ and Al3) bridge the $\mathrm{C}_{3} \mathrm{~N}_{2}$ rings in a manner similar to that in compound $\mathbf{1}$ to give a six-membered $\mathrm{Al}_{2} \mathrm{~N}_{4}$ ring in a twist-conformation. The third aluminum atom (Al1) bridges this ring to give a bicyclic, norbornanelike molecular structure. All aluminum atoms have a coordination number of four. The $\mathrm{Al}-\mathrm{N}$ distances differ markedly. The shortest distance (185.7 pm) occurs between $\mathrm{Al} 3$ and the negatively charged, tricoordinated nitrogen atom N3 (sum of the angles $359.2^{\circ}$ ). The distance between the $s p^{2}$-hybridized imino nitrogen atom $\mathrm{N} 2$ (sum of the angles $359.6^{\circ}$ ), and Al2 (200.0 pm) is considerably longer. All other $\mathrm{Al}-\mathrm{N}$ bond lengths between tetracoordinated aluminum and nitrogen atoms are in the range of 193.5 to $201.8 \mathrm{pm}$. The ring hydrogen atoms, which have resulted from the hydroalu- mination of the $\mathrm{C}=\mathrm{N}$ bonds, are on the same side of the heterocyclic ring system and opposite to the $\mathrm{AlEt}_{2}$ group bridging the central $\mathrm{Al}_{2} \mathrm{~N}_{4}$ ring.

The results of the NMR spectroscopic characterization are in complete agreement with the solidstate molecular structure and the different degrees of hydroalumination of the pyrazole rings. However, very complicated spectra result in accordance with the molecular symmetry. The ethyl substituents gave broad multiplets in the ${ }^{1} \mathrm{H}$ NMR spectrum between $\delta=-0.14$ and +0.58 for their $\mathrm{CH}_{2}$ and between $\delta=$ 1.36 and 1.46 for their $\mathrm{CH}_{3}$ groups which could not be resolved and assigned to particular positions in the molecule. However, in the ${ }^{13} \mathrm{C}$ NMR spectrum the expected six resonances of the ethyl $\mathrm{CH}_{3}$ groups were observed in the narrow range between $\delta=10.4$ and 10.9. Three doublets were identified in the ${ }^{1} \mathrm{H}$ NMR spectrum for the methyl groups attached to the $\mathrm{C}(\mathrm{H})$ atoms of the $\mathrm{C}_{3} \mathrm{~N}_{2}$ heterocycles $(\mathrm{C} 1, \mathrm{C} 4$ and $\mathrm{C} 6$, according to Fig. 2). Four singlets resulted for the chemically different methyl groups at the carbon atoms $\mathrm{C} 2$ and $\mathrm{C}$, and three quartets with equal intensity are characteristic of the hydrogen atoms attached to $\mathrm{C} 1, \mathrm{C} 4$ and $\mathrm{C} 6$. A resonance at $\delta=175.8(\mathrm{C} 3)$ in the ${ }^{13} \mathrm{C}$ NMR spectrum is indicative of the remaining $\mathrm{N}=\mathrm{C}$ double bond, while the $s p^{3}$-hybridized carbon atoms in the $\mathrm{C}_{3} \mathrm{~N}_{2}$ rings which were generated by hydroalumination $(\mathrm{C} 1$, C4, C6) have resonances at $\delta=63.4,64.2$ and 64.7.

Compound $\mathbf{3}$ is formally formed by the reaction of the starting compounds in a molar ratio of $3: 2$ (aluminum hydride versus pyrazole). However, when the reaction is conducted with exactly this stoichiometric ratio at r.t. the resonances of $\mathbf{3}$ could not be detected in the NMR spectra. Heating in toluene for several days is required to form $\mathbf{3}$ under these conditions. Complete hydroalumination of all $\mathrm{C}=\mathrm{N}$ double bonds was not achieved when the solutions were stirred for longer periods or heated under reflux $\left(111^{\circ} \mathrm{C}\right)$. Even a large excess of the hydride (up to a ratio of $9: 1$ ) yielded compound $\mathbf{3}$ as the only product.

\section{Reaction of 3,5-diphenylpyrazole with $\left(\mathrm{Me}_{3} \mathrm{C}\right)_{2} \mathrm{Al}-\mathrm{H}$}

Hydrogen atoms bonded to a pyrazole ring can be redistributed to produce a tautomeric form which contains an $\mathrm{N}-\mathrm{H}$ group and a $\mathrm{C}=\mathrm{C}$ beside a $\mathrm{C}=\mathrm{N}$ double bond. The N-H function is relatively acidic, and treatment with dialkylaluminum hydride therefore may not result in hydroalumination as described before, 


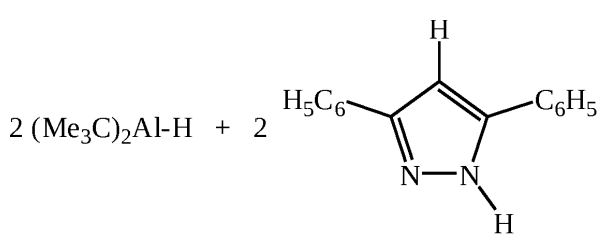

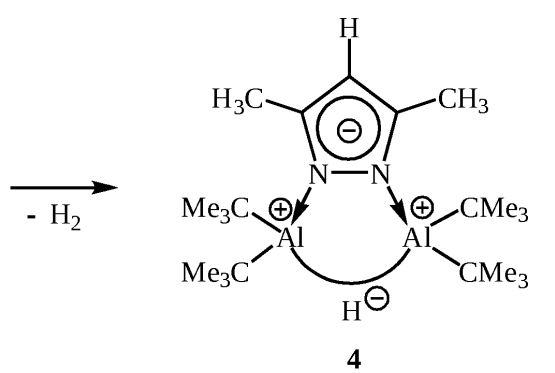

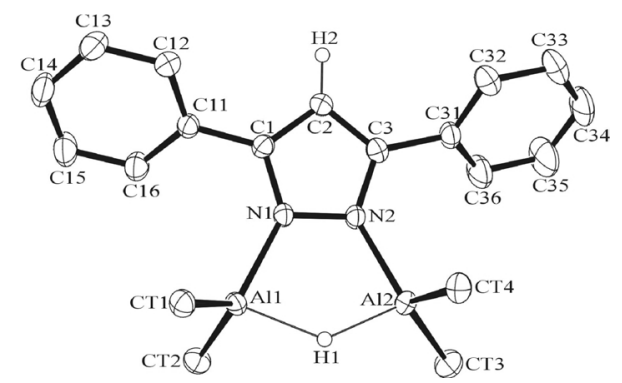

Fig. 3. Molecular structure of 4. The ellipsoids are drawn at the $40 \%$ probability level; methyl groups and phenyl hydrogen atoms are omitted. Selected bond lengths (pm) and angles (deg): Al1-N1 195.1(2), Al2-N2 195.3(2), Al1-H1 177(2), Al2-H1 169(2), N1-N2 138.3(2), N1-C1 135.1(3), N2-C3 135.1(3), C1-C2 138.6(3), C2-C3 138.3(3); Al1N1-N2 117.5(1), A12-N2-N1 116.2(1).

but lead to deprotonation and release of hydrogen. We observed such a reaction when we treated 3,5diphenylpyrazole with di(tert-butyl)aluminum hydride (Eq. 4). Complete consumption of the starting compounds was only observed for a molar ratio of $2: 1$ (hydride versus pyrazole). Colorless crystals of the product (4) were isolated after concentration of the reaction mixture and cooling to $-15{ }^{\circ} \mathrm{C}$ in $60 \%$ yield. The molecular structure of compound 4 (Fig. 3) consists of two aluminum atoms which have two terminal tertbutyl substituents and are bridged by a pyrazole ring and a hydrogen atom via a $3 \mathrm{c}-2 \mathrm{e} \mathrm{Al}-\mathrm{H}-\mathrm{Al}$ bridge. 4 is clearly formed by hydrogen release and coordination of a second molecule of the starting hydride. Each nitrogen atom of the pyrazole ring is coordinated to an aluminum atom with almost indistinguishable $\mathrm{Al}-\mathrm{N}$ distances of 195.1(2) and 195.3(2) pm. The complete delocalization of the $\pi$ electron density and the aromatic character of the pyrazole ring is evident from the quite similar $\mathrm{C}-\mathrm{N}$ [C1-N1 and C3-N2 135.1(3) pm], $\mathrm{N}-\mathrm{N}[138.3(2) \mathrm{pm}]$ and $\mathrm{C}-\mathrm{C}$ bond lengths [C1-C2 138.6(3) and C2-C3 138.3(3) pm] [15]. The $\mathrm{Al}_{2} \mathrm{~N}_{2} \mathrm{H}$ ring is almost ideally planar with a maximum deviation of an atom from the average plane of only $6 \mathrm{pm}$. The normals of both heterocycles enclose an angle of $17.4^{\circ}$. The benzene rings are tilted with respect to the pyrazole plane by 41.1 and $48.4^{\circ}$. All NMR data are in complete agreement with the solid-state molecular structure, and no detailed discussion is required. A similar compound has been obtained previously by the corresponding reaction with diisobutylaluminum hydride [16]. Its constitution analogous to that of $\mathbf{4}$ was not established by crystal structure determination, but by NMR spectroscopy and structures of secondary products.

\section{Experimental Section}

All procedures were carried out under purified argon in dried solvents ( $n$-pentane and $n$-hexane over $\mathrm{LiAlH}_{4}$, toluene over $\mathrm{Na} /$ benzophenone). Tetramethylpyrazole [17], 3,5-diphenylpyrazole [18], di(tert-butyl)- [19] and diethylaluminum hydride [20] were obtained according to literature procedures.

Reaction of tetramethylpyrazole with di(tert-butyl)aluminum hydride in a molar ratio of $1: 1$; synthesis of 1

$\left(\mathrm{Me}_{3} \mathrm{C}\right)_{2} \mathrm{AlH}(0.200 \mathrm{~g}, 1.41 \mathrm{mmol})$, dissolved in $20 \mathrm{~mL}$ of $n$-pentane was added to a solution of tetramethylpyrazole $(0.175 \mathrm{~g}, 1.41 \mathrm{mmol})$ in $20 \mathrm{~mL}$ of toluene at $\mathrm{r}$. t. The color changed from yellow to orange red. The solution was stirred at r. t. for $18 \mathrm{~h}$ and concentrated. Colorless crystals of $\mathbf{1}$ precipitated upon cooling to $+3{ }^{\circ} \mathrm{C}$. Yield: $0.126 \mathrm{~g}(34 \%)$. M. p. (under argon, sealed capillary): $220{ }^{\circ} \mathrm{C}$ (dec.). - IR (paraffin; $\mathrm{CsBr}$ plates): $v=1580 \mathrm{~m}, 1560 \mathrm{~m} v(\mathrm{C}=\mathrm{N}) ; 1462$ vs, 1377 vs (paraffin); $1314 \mathrm{~m}, 1287 \mathrm{w} \delta\left(\mathrm{CH}_{3}\right) ; 1163 \mathrm{~m}$, $1059 \mathrm{~s}, 1042 \mathrm{~s}, 1016 \mathrm{~m}, 997 \mathrm{~m}, 949 \mathrm{~s}, 928 \mathrm{~m}, 806 \mathrm{~s} v(\mathrm{CC})$, $v(\mathrm{CN}) ; 723 \mathrm{~s}$ (paraffin); $687 \mathrm{~m}, 629 \mathrm{w}, 611 \mathrm{~m}, 581 \mathrm{~m}$, $563 \mathrm{~m}, 542 \mathrm{~m}, 476 \mathrm{~cm}^{-1} \mathrm{~s} v(\mathrm{AlC}), v(\mathrm{AlN}), \delta(\mathrm{CC}) .-{ }^{1} \mathrm{H}$ NMR (400 MHz, $\left.\mathrm{C}_{6} \mathrm{D}_{6}\right): d=3.86\left(\mathrm{q},{ }^{3} J_{\mathrm{H}-\mathrm{H}}=6.6 \mathrm{~Hz}, 2 \mathrm{H}\right.$, $\mathrm{NCH}), 1.70$ (s, $\left.6 \mathrm{H}, \mathrm{N}=\mathrm{C}-\mathrm{CH}_{3}\right), 1.40$ and 1.11 (each s, $18 \mathrm{H}$, $\left.\mathrm{CMe}_{3}\right), 1.09\left(\mathrm{~d},{ }^{3} \mathrm{~J}_{\mathrm{H}-\mathrm{H}}=6.6 \mathrm{~Hz}, 6 \mathrm{H}, \mathrm{N}-\mathrm{CH}-\mathrm{CH}_{3}\right), 1.03$ and 0.73 (each s, 6H, CMe 2 ). $-{ }^{13} \mathrm{C} \mathrm{NMR}\left(100 \mathrm{MHz}, \mathrm{C}_{6} \mathrm{D}_{6}\right)$ : $\delta=159.0(\mathrm{~N}=\mathrm{C}), 65.2(\mathrm{~N}-\mathrm{C}), 49.3\left(\mathrm{CMe}_{2}\right), 33.0$ and 32.0 $\left(\mathrm{CMe}_{3}\right), 25.2$ and $19.5\left(\mathrm{CMe} e_{2}\right), 19.1\left(\mathrm{~N}-\mathrm{CH}-\mathrm{CH}_{3}\right), 17.2$ and $15.7\left(\mathrm{CMe}_{3}\right), 13.5\left(\mathrm{~N}=\mathrm{C}-\mathrm{CH}_{3}\right) .-\mathrm{MS}\left(\mathrm{EI}, 20 \mathrm{eV}, 70{ }^{\circ} \mathrm{C}\right): \mathrm{m} / \mathrm{z}$ $(\%)=475$ (100), $476(30)[\mathrm{M}-t \mathrm{Bu}-\text { butene }]^{+}$. 
Reaction of tetramethylpyrazole with di(tert-butyl)aluminum hydride in a molar ratio of $1: 2$; synthesis of 2

$\left(\mathrm{Me}_{3} \mathrm{C}\right)_{2} \mathrm{AlH}(0.444 \mathrm{~g}, 3.13 \mathrm{mmol})$, dissolved in $20 \mathrm{~mL}$ of $n$-pentane, was added to a solution of tetramethylpyrazole $(0.194 \mathrm{~g}, 1.56 \mathrm{mmol})$ in $20 \mathrm{~mL}$ of toluene at r.t. The color changed from yellow to deep red. The solution was stirred at $+50{ }^{\circ} \mathrm{C}$ for $12 \mathrm{~h}$. Yellow crystals of 2 precipitated after concentration and cooling to $+3{ }^{\circ} \mathrm{C}$. Yield: $0.457 \mathrm{~g}(72 \%)$. M. p. (under argon, sealed capillary): $143{ }^{\circ} \mathrm{C}$. - IR (paraffin; $\mathrm{CsBr}$ plates): $v=1585 \mathrm{~m} v(\mathrm{C}=\mathrm{N}) ; 1458 \mathrm{vs}, 1377$ vs (paraffin); $1323 \mathrm{~m}, 1310 \mathrm{~m}, 1271 \mathrm{w} \delta\left(\mathrm{CH}_{3}\right) ; 1169 \mathrm{~s}, 1144$ m, $1103 \mathrm{~m}, 1076 \mathrm{~s}, 1061 \mathrm{~s}, 1030 \mathrm{~m}, 1016 \mathrm{~m}, 1001 \mathrm{~s}, 951 \mathrm{~s}$, $935 \mathrm{~s}, 841 \mathrm{w}, 812 \mathrm{vs}, 779 \mathrm{w} v(\mathrm{CC}), v(\mathrm{CN}) ; 723 \mathrm{vs}$ (paraffin); 708 vs, $615 \mathrm{~m}, 575 \mathrm{w}, 540 \mathrm{w}, 495 \mathrm{w}, 457 \mathrm{~cm}^{-1} \mathrm{~s} v(\mathrm{AlC})$, $v(\mathrm{AlN}), \delta(\mathrm{CC}) .-{ }^{1} \mathrm{H}$ NMR $\left(400 \mathrm{MHz}, \mathrm{C}_{6} \mathrm{D}_{6}\right): \delta=3.43$ $\left(\mathrm{qq},{ }^{3} J_{\mathrm{H}-\mathrm{H}}=6.7 \mathrm{~Hz},{ }^{5} J_{\mathrm{H}-\mathrm{H}}=1.0 \mathrm{~Hz}, 1 \mathrm{H}, \mathrm{NCH}\right), 2.97(\mathrm{~s}$, br., $1 \mathrm{H}, \mathrm{AlH}), 1.49\left(\mathrm{~d},{ }^{5} \mathrm{~J}_{\mathrm{H}-\mathrm{H}}=1.0 \mathrm{~Hz}, 3 \mathrm{H}, \mathrm{N}=\mathrm{C}-\mathrm{CH}_{3}\right)$, $1.28,1.26,1.183$ and 1.177 (each s, 9H, $\left.\mathrm{CMe}_{3}\right), 0.98$ (d, $\left.{ }^{3} J_{\mathrm{H}-\mathrm{H}}=6.7 \mathrm{~Hz}, 3 \mathrm{H}, \mathrm{N}-\mathrm{CH}-\mathrm{CH}_{3}\right), 0.63$ and 0.48 (each s, $3 \mathrm{H}$, $\left.\mathrm{CMe}_{2}\right) .-{ }^{13} \mathrm{C}$ NMR $\left(100 \mathrm{MHz}, \mathrm{C}_{6} \mathrm{D}_{6}\right): \delta=155.9(\mathrm{~N}=\mathrm{C})$, $66.6(\mathrm{~N}-\mathrm{C}), 50.0\left(\mathrm{CMe}_{2}\right), 32.0,31.7,31.3$ and $31.2\left(\mathrm{CMe}_{3}\right)$, 22.9 and $15.7\left(\mathrm{CMe}_{2}\right), 17.3,16.3$ and 15.6 (two resonances coincide) $\left(\mathrm{CMe}_{3}\right), 12.7\left(\mathrm{~N}-\mathrm{CH}-\mathrm{CH}_{3}\right), 12.4\left(\mathrm{~N}=\mathrm{C}-\mathrm{CH}_{3}\right)$. MS (EI, $\left.20 \mathrm{eV}, 30^{\circ} \mathrm{C}\right): \mathrm{m} / \mathrm{z}(\%)=351(100), 352$ (22) [M$t \mathrm{Bu}]^{+}$.

\section{Reaction of tetramethylpyrazole with diethylaluminum hydride in a molar ratio of $1: 2$; synthesis of 3}

$\mathrm{Et}_{2} \mathrm{AlH}(0.5 \mathrm{~mL}, 0.400 \mathrm{~g}, 4.65 \mathrm{mmol})$, dissolved in $10 \mathrm{~mL}$ of $n$-pentane, was added to a solution of tetramethylpyrazole $(0.285 \mathrm{~g}, 2.30 \mathrm{mmol})$ in $20 \mathrm{~mL}$ of toluene at r.t. The color changed from yellow to deep red. The solution was stirred at r.t. for $12 \mathrm{~h}$. Yellow crystals of $\mathbf{2}$ precipitated after concentration and cooling to $+3{ }^{\circ} \mathrm{C}$. Yield: $0.387 \mathrm{~g}(67 \%)$. M. p. (under argon, sealed capillary): $186{ }^{\circ} \mathrm{C}$. - IR (paraffin; $\mathrm{CsBr}$ plates): $v=1556 \mathrm{~m} v(\mathrm{C}=\mathrm{N}) ; 1460 \mathrm{vs}, 1377$ vs (paraffin); $1304 \mathrm{~m} \delta\left(\mathrm{CH}_{3}\right) ; 1192 \mathrm{~m}, 1109 \mathrm{~m}, 1088 \mathrm{w}, 1026$ w, $986 \mathrm{~m}, 955 \mathrm{~m}, 918 \mathrm{~m}, 891 \mathrm{~m}, 773 \mathrm{~m} v(\mathrm{CC}), v(\mathrm{CN}) ; 721$ $\mathrm{s}$ (paraffin); $689 \mathrm{~m}, 642 \mathrm{~s}, 573 \mathrm{w}, 548 \mathrm{w} \mathrm{cm}^{-1} \mathrm{~s} v(\mathrm{AlC})$, $v(\mathrm{AlN}), \delta(\mathrm{CC}) .-{ }^{1} \mathrm{H}$ NMR $\left(400 \mathrm{MHz}, \mathrm{C}_{6} \mathrm{D}_{6}\right): \delta=3.36(\mathrm{q}$, ${ }^{3} J_{\mathrm{H}-\mathrm{H}}=6.8 \mathrm{~Hz}, 1 \mathrm{H}, \mathrm{NCH}$ of the unsaturated ring), 3.150 (q, ${ }^{3} J_{\mathrm{H}-\mathrm{H}}=6.6 \mathrm{~Hz}, 1 \mathrm{H}, \mathrm{NCH}$ of the saturated ring), 3.146 $\left(\mathrm{q},{ }^{3} J_{\mathrm{H}-\mathrm{H}}=6.4 \mathrm{~Hz}, 1 \mathrm{H}, \mathrm{NCH}\right.$ of the saturated ring), $1.53(\mathrm{~s}$, $\left.3 \mathrm{H}, \mathrm{N}=\mathrm{C}-\mathrm{CH}_{3}\right), 1.46$ to $1.36\left(\mathrm{~m}, 18 \mathrm{H}, \mathrm{CH}_{3}\right.$ of ethyl), 1.18 $\left(\mathrm{d},{ }^{3} \mathrm{~J}_{\mathrm{H}-\mathrm{H}}=6.4 \mathrm{~Hz}, 3 \mathrm{H}, \mathrm{N}-\mathrm{CH}-\mathrm{CH}_{3}\right.$ of the saturated ring), $1.14\left(\mathrm{~d},{ }^{3} \mathrm{~J}_{\mathrm{H}-\mathrm{H}}=6.6 \mathrm{~Hz}, 3 \mathrm{H}, \mathrm{N}-\mathrm{CH}-\mathrm{CH}_{3}\right.$ of the saturated ring), $1.06\left(\mathrm{~d},{ }^{3} J_{\mathrm{H}-\mathrm{H}}=6.8 \mathrm{~Hz}, 3 \mathrm{H}, \mathrm{N}-\mathrm{CH}-\mathrm{CH}_{3}\right.$ of the unsaturated ring), 0.77 and 0.71 (each s, $3 \mathrm{H}, \mathrm{CMe}_{2}$ of the saturated ring), 0.55 and 0.50 (each $\mathrm{s}, 3 \mathrm{H}, \mathrm{CMe}_{2}$ of the unsaturated ring), 0.58 to $-0.14\left(\mathrm{~m}, 12 \mathrm{H}, \mathrm{CH}_{2}\right.$ of ethyl). $-{ }^{13} \mathrm{C} \mathrm{NMR}$ $\left(100 \mathrm{MHz}, \mathrm{C}_{6} \mathrm{D}_{6}\right): \delta=175.8(\mathrm{~N}=\mathrm{C}), 64.2$ and $64.7(\mathrm{~N}-\mathrm{C}$ of the saturated ring), 63.4 (N-C of the unsaturated ring), 53.5
Table 1. Crystal data, data collection, and structure refinement.

\begin{tabular}{|c|c|c|c|}
\hline & 1-toluene & 3 & 4 \\
\hline \multicolumn{4}{|l|}{ Crystal data } \\
\hline Empirical formula & $\mathrm{C}_{37} \mathrm{H}_{70} \mathrm{Al}_{2} \mathrm{~N}_{4}$ & $\mathrm{C}_{26} \mathrm{H}_{57} \mathrm{Al}_{3} \mathrm{~N}_{4}$ & $\mathrm{C}_{31} \mathrm{H}_{48} \mathrm{Al}_{2} \mathrm{~N}_{2}$ \\
\hline$M_{\mathrm{r}}$ & 624.93 & 506.70 & 502.67 \\
\hline Crystal system & \multicolumn{3}{|c|}{ - monoclinic - } \\
\hline Space group [22] & $P 2_{1} / n$ & $P 2_{1} / n$ & $P 2_{1} / c$ \\
\hline$a, \mathrm{pm}$ & $1206.32(5)$ & $1006.67(3)$ & $902.00(6)$ \\
\hline$b, \mathrm{pm}$ & 2231.1(1) & $1748.18(6)$ & $4565.8(3)$ \\
\hline$c, \mathrm{pm}$ & $1456.69(6)$ & $1764.62(6)$ & $819.76(4)$ \\
\hline$\beta, \operatorname{deg}$ & $95.112(3)$ & $95.600(1)$ & $113.228(4)$ \\
\hline$V, \times 10^{-30} \mathrm{~m}^{3}$ & $3905.0(3)$ & $3090.6(2)$ & $3102.4(3)$ \\
\hline$\rho_{\text {calc }}, \mathrm{g} \mathrm{cm}^{-3}$ & 1.06 & 1.09 & 1.08 \\
\hline$Z$ & 4 & 4 & 4 \\
\hline$F(000), \mathrm{e}$ & 1384 & 1120 & 1096 \\
\hline$\mu, \mathrm{mm}^{-1}$ & $0.9\left(\mathrm{Cu} K_{\alpha}\right)$ & $0.1\left(\mathrm{Mo} K_{\alpha}\right)$ & $1.0\left(\mathrm{Cu} K_{\alpha}\right)$ \\
\hline \multicolumn{4}{|l|}{ Data collection } \\
\hline$T, \mathrm{~K}$ & $153(2)$ & $153(2)$ & $153(2)$ \\
\hline Radiation & $\mathrm{Cu} K_{\alpha}$ & $\operatorname{Mo} K_{\alpha}$ & $\mathrm{Cu} K_{\alpha}$ \\
\hline Unique reflectio & 7345 & 7079 & 5841 \\
\hline Reflections $I \geq 2 \sigma(I)$ & 5743 & 5479 & 4701 \\
\hline \multicolumn{4}{|l|}{ Refinement } \\
\hline Refined parameters & 411 & 332 & 332 \\
\hline Final $R[I \geq 2 \sigma(I)]^{\mathrm{a}}$ & 0.062 & 0.064 & 0.056 \\
\hline Final $w R 2^{\overline{\mathrm{b}}}$ (all data) & 0.176 & 0.181 & 0.144 \\
\hline$\left.\underset{\mathrm{e} \AA^{-3}}{\Delta \rho_{\text {fin }}(\max } / \mathrm{min}\right)$ & $0.92 /-0.34$ & $1.08 /-0.65$ & $0.46 /-0.26$ \\
\hline
\end{tabular}

( $C \mathrm{Me}_{2}$ of the unsaturated ring), $46.2\left(C \mathrm{Me}_{2}\right.$ of the saturated ring), 25.0 and 18.5 ( $\mathrm{CMe}_{2}$ of the unsaturated ring), 23.8 and $14.8\left(\mathrm{CMe}_{2}\right.$ of the saturated ring), 14.9 and $14.8\left(\mathrm{~N}-\mathrm{CH}-\mathrm{CH}_{3}\right.$ of the saturated ring), $14.6\left(\mathrm{~N}-\mathrm{CH}-\mathrm{CH}_{3}\right.$ of the unsaturated ring $), 12.8\left(\mathrm{~N}=\mathrm{C}-\mathrm{CH}_{3}\right), 10.92,10.88,10.63,10.53,10.40$ and $10.39\left(\mathrm{CH}_{3}\right.$ of ethyl), 3.6, 2.7, 1.9 and 0.2 (broad resonances of $\left.\mathrm{AlCH}_{2}\right)$. - MS (EI, $\left.20 \mathrm{eV}, 60{ }^{\circ} \mathrm{C}\right): \mathrm{m} / \mathrm{z}(\%)=506$ (3) $[\mathrm{M}]^{+}, 477$ (67), 478 (16) $[\mathrm{M}-\mathrm{Et}]^{+}, 391$ (43) [M-EtH$\left.\mathrm{AlEt}_{2}\right]^{+}$.

Reaction of 3,5-diphenylpyrazole with di(tert-butyl)aluminum hydride; synthesis of $\mathbf{4}$

$\left(\mathrm{Me}_{3} \mathrm{C}\right)_{2} \mathrm{AlH}(0.482 \mathrm{~g}, 3.39 \mathrm{mmol})$, dissolved in $10 \mathrm{~mL}$ of $n$-hexane, was added to a suspension of 3,5-diphenylpyrazole $(0.373 \mathrm{~g}, 1.69 \mathrm{mmol})$ in $20 \mathrm{~mL}$ of toluene at $-30{ }^{\circ} \mathrm{C}$. The solid dissolved readily, and a clear, yellow solution resulted. The solution was warmed to r.t. over a period of $12 \mathrm{~h}$. Colorless crystals of $\mathbf{4}$ precipitated after concentration and cooling to $-15{ }^{\circ} \mathrm{C}$. Yield: $0.513 \mathrm{~g}(60 \%)$. - M. p. (under argon, sealed capillary): $134{ }^{\circ} \mathrm{C}$. - IR (paraffin; CsBr plates): $v=1558 \mathrm{w}, 1543 \mathrm{~m}$ phenyl, pyrazole; $1462 \mathrm{vs}, 1377 \mathrm{~s}$ (paraffin); $1300 \mathrm{w}, 1275 \mathrm{w} \delta\left(\mathrm{CH}_{3}\right) ; 1182 \mathrm{w}, 1157 \mathrm{w}, 1098$ m, 1069 m, 1003 m, 972 w, 934 w, 916 w, 812 m, 758 s $v(\mathrm{CC}), v(\mathrm{CN}) ; 723 \mathrm{w}$ (paraffin); $698 \mathrm{~s}$ phenyl; $671 \mathrm{w}, 579$ 
$\mathrm{w}, 556 \mathrm{w}, 451 \mathrm{~cm}^{-1} \mathrm{~m} \mathrm{v}(\mathrm{AlC}), v(\mathrm{AlN}), \delta(\mathrm{CC}) .-{ }^{1} \mathrm{H}$ NMR $\left(400 \mathrm{MHz}, \mathrm{C}_{6} \mathrm{D}_{6}\right): \delta=7.48(\mathrm{~m}, 4 \mathrm{H}$, ortho- $\mathrm{H}$ of phenyl), $7.16(\mathrm{~m}, 4 \mathrm{H}$, meta- $\mathrm{H}$ of phenyl), $7.09(\mathrm{~m}, 2 \mathrm{H}$, para $-\mathrm{H}$ of phenyl), 6.35 (s, 1H, pyrazole), 3.41 (s, br., 1H, AlHAl), 1.17 (s, 36H, CMe 3$).-{ }^{13} \mathrm{C}$ NMR (100 MHz, $\left.\mathrm{C}_{6} \mathrm{D}_{6}\right): \delta=$ 156.1 (NC of pyrazole), 131.4 (ipso-C of phenyl), 130.1 (para-C of phenyl), 129.6 (meta-C of phenyl), 127.8 (ortho-C of phenyl), 106.9 ( $\mathrm{CH}$ of pyrazole), $31.2\left(\mathrm{CMe}_{3}\right), 16.8$ $\left(\mathrm{CMe}_{3}\right) .-\mathrm{MS}\left(\mathrm{EI}, 20 \mathrm{eV}, 30^{\circ} \mathrm{C}\right): \mathrm{m} / \mathrm{z}(\%)=445(100), 446$ (29) $[\mathrm{M}-t \mathrm{Bu}]^{+}$.

\section{Crystal structure determinations}

Single crystals were obtained upon cooling of the reaction mixtures as described above. Data collections were performed on Bruker SMART APEX-II (MoK $K_{\alpha}$ radiation) and Bruker SMART $6000\left(\mathrm{Cu} K_{\alpha}\right.$ radiation) diffractometers. The structures were solved by Direct Methods and refined by full- matrix least-squares calculations based on $F^{2}$ [21]. Hydrogen atoms with the exception of $\mathrm{Al}-\mathrm{H}$ were calculated on ideal positions and refined by the riding model. Crystal data, data collection parameters and details of the structure refinement are given in Table 1 . The crystals of $\mathbf{1}$ enclosed a molecule of toluene per formula unit of the tricyclic compound. The methyl group of an ethyl substitutent (C60) of $\mathbf{3}$ was disordered over three positions; the atoms were refined with occupation factors of 0.33 .

CCDC 767773 (1), 767772 (3) and 767774 (4) contain the supplementary crystallographic data for this paper. These data can be obtained free of charge from The Cambridge Crystallographic Data Centre via www.ccdc.cam.ac.uk /data_request/cif.

\section{Acknowledgement}

We are grateful to the Deutsche Forschungsgemeinschaft for generous financial support.
[1] W. Uhl, in Group 13 Chemistry III - Industrial Applications, (Eds.: H. W. Roesky, D. A. Atwood), Structure and Bonding, Springer Verlag, 2003, p. 41.

[2] C. Lustig, N. W. Mitzel, Angew. Chem. 2001, 113, 4521; Angew. Chem. Int. Ed. 2001, 40, 4390; N.W. Mitzel, C. Lustig, M. Woski, Dalton Trans. 2004, 397; P. Bösing, A. Willner, T. Pape, A. Hepp, N. W. Mitzel, Dalton Trans. 2008, 2549.

[3] A. R. Barron, Chem. Soc. Rev. 1993, 22, 93; W. Uhl, M. R. Halvagar, Angew. Chem. 2008, 120, 1981; Angew. Chem. Int. Ed. 2008, 47, 1955; W. Uhl, M. R. Halvagar, F. Rogel, W. Massa, Eur. J. Inorg. Chem. 2009, 489; W. Uhl, M. R. Halvagar, M. Layh, Chem. Commun. 2009, 4269; W. Uhl, M. R. Halvagar, M. Claesener, Chem. Eur. J. 2009, 15, 11298; W. Uhl, B. Jana, Chem. Eur. J. 2008, 14, 3067.

[4] W. Uhl, T. Abel, J. Kösters, F. Rogel, Z. Naturforsch. 2008, 63b, 117; W. Uhl, C. H. Emden, G. Geiseler, K. Harms, Z. Anorg. Allg. Chem. 2003, 629, 2157.

[5] W. Uhl, T. Abel, A. Hepp, S. Grimme, M. Steinmetz, Eur. J. Inorg. Chem. 2008, 543.

[6] W. Uhl, T. Abel, J. Kösters, B. Rezaeirad, Z. Anorg. Allg. Chem. 2009, 635, 1014.

[7] W. Uhl, T. Abel, A. Hepp, T. Nilges, F. Rogel, E.-U. Würthwein, N. Ghavtadse, Inorg. Chem. 2009, 48, 752.

[8] W. Uhl, A. Vogelpohl, Z. Naturforsch. 2008, 63b, 1149; W. Uhl, A. Vogelpohl, J. Kösters, Z. Naturforsch. 2006, $61 b, 854$; W. Uhl, C. H. Emden, W. Massa, J. Organomet. Chem. 2006, 691, 1382.

[9] W. Uhl, A. Vogelpohl, Eur. J. Inorg. Chem. 2009, 93.

[10] W. Uhl, J. Molter, B. Neumüller, Chem. Eur. J. 2001, 7, 1510; see also: R. J. Wehmschulte, P. P. Power, Inorg. Chem. 1996, 35, 2717.
[11] W. Uhl, J. Molter, B. Neumüller, F. Schmock, Z. Anorg. Allg. Chem. 2001, 627, 909; W. Uhl, J. Molter, B. Neumüller, J. Organomet. Chem. 2001, 634, 193.

[12] $\mathrm{N}_{2} \mathrm{H}_{4}$ : Y. Morino, T. Iijima, Y. Murata, Bull. Chem. Soc. Jpn. 1960, 33, 46; $\mathrm{N}_{2}\left(\mathrm{SiH}_{3}\right)_{4}$ : C. Glidewell, D. W.H. Rankin, A. G. Robiette, G. M. Sheldrick, J. Chem. Soc. A 1970, 318; $\mathrm{N}_{2} \mathrm{~F}_{4}$ : M. M. Gilbert, G. Gundersen, K. Hedberg, J. Chem. Phys. 1972, 56, 1691; J.R. Durig, Z. Shen, J. Chem. Phys. A 1997, 101, 5010; $\mathrm{N}_{2} \mathrm{Me}_{4}$ : V. A. Naumov, O. A. Litvinov, H. J. Geise, J. Dillen, J. Mol. Struct. 1983, 99, 303; review: K. Bode, U. Klingebiel, Adv. Organomet. Chem. 1996, 40, 1; S. Dielkus, C. Drost, R. Herbst-Irmer, U. Klingebiel, Angew. Chem. 1993, 105, 1689; Angew. Chem., Int. Ed. Engl. 1993, 32, 1625.

[13] R. Boucourt, in Topics in Stereochemistry, (Eds.: E. L. Eliel, N. L. Allinger), Vol. 8, Wiley, New York, 1974, p. 159.

[14] F. Garcia, A. D. Hopkins, R. A. Kowenicki, M. McPartlin, J. S. Silvia, J. M. Rawson, M. C. Rogers, D. S. Wright, Chem. Commun. 2007, 586.

[15] Lithium, magnesium and aluminum pyrazolates: S. Beaini, G. B. Deacon, A. P. Erven, P. C. Junk, D. R. Turner, Chem. Asian J. 2007, 2, 539; J. Hitzbleck, G. B. Deacon, K. Ruhlandt-Senge, Eur. J. Inorg. Chem. 2007, 582; S. A. Cortes-Liamas, M. A. MunozHernandez, Organometallics 2007, 26, 6844.

[16] Z. Yu, J. M. Wittbrodt, A. Xia, M. J. Heeg, H. B. Schlegel, C. H. Winter, Organometallics 2001, 20, 4301.

[17] K. Beck, A. Höhn, S. Hünig, F. Prokschy, Chem. Ber. 1984, 117, 517 
[18] J. Elguero, E. Gonzales, R. Jacquier, Bull. Chem. Soc. Fr. 1968, 707.

[19] W. Uhl, L. Cuypers, R. Graupner, J. Molter, A. Vester, B. Neumüller, Z. Anorg. Allg. Chem. 2001, 627, 607.

[20] H. Lehmkuhl, K. Ziegler, Methoden Org. Chem. (Houben-Weyl), 4th ed., Vol. XIII/4, Thieme, Stuttgart, 1952, p. 58

[21] G. M. Sheldrick, ShelXTL-Plus (version 4.1), Siemens Analytical X-Ray Instruments Inc., Madison,
Wisconsin (USA) 1990; G. M. Sheldrick, SHELXL-97, Program for the Refinement of Crystal Structures, University of Göttingen, Göttingen (Germany) 1997. See also: G. M. Sheldrick, Acta Crystallogr. 2008, A64, 112.

[22] T. Hahn (Ed.), International Tables for Crystallography, Space-Group Symmetry, Vol. A, Kluwer Academic Publishers, Dordrecht-Boston-London, 1989. 